\title{
下顎切除症例の遠隔成績について
}

\section{一一第1 報 成長期患者についての調查結果—}

名倉英明 - 曾田忠雄 - 白石豊彦 - 伊藤秀夫

\section{The follow-up study of the cases of mandiblectomy \\ I The results of patients in growing stage}

\author{
Hideaki Nagura - Tadao Soda $\cdot$ Toyohiko Shiraishi $\cdot$ Hideo ItoH
}

\section{緒}

$\overline{\overline{\bar{⿳}}}$

下靧の腫瘍および腫瘍様病変に対して，下䋶切除術が 適用される症例が少なくないが，その場合には，切除に よる顔貌の変形ならびに罘機能の啔失, または低下を最 小限にとどめるために，骨移植による再建手術が併用さ れることが多い，当教室の㴿部骨移植成績については, すでに中村1)および加子ら²)によって報告されており， その他の内外の業績をみても，ほ注期待に価する成果が 得られている.

しかし，患者がまだ成長期にある年少者の場合には， 腸骨稜から採取できる移植骨片の大きさに限度があり, また骨移植後の顎間固定法にも種々の制約があるので, 下䫕切除直後の骨移植による再建が，必ずしも最良とは い兄ない症例もあるように思われる。そこで，われわれ は当科で経験した年少者の下顎切除症例について, 切除 部分の骨形成状態, 骨移植部の状態, 下靧の偏位, 顔貌 の変形および咬合状態などを中心に遠隔調査を行い，骨 移植術の適応症の選択資するであろう興味ある結果が 得られたので，その概要を報告する。

\section{調 查 対 象}

今回の調査の対象は, 昭和 39 年より同 51 年末をでの 13 年間に下顎切除が行われた 129 例のうちの，19歳未満の 18例（約14\%）である。患者の手術時の年跉は，10歳以 下が 2 例, 11〜 15歳が 5 例, 16〜19歳が11例であり, 調 査時点までの期間は最短 1 年 4 か月から最長13年までで ある。なお，疾患別はエナメル上皮腫10例，化骨性線維 腫 4 例, セメント質線維腫 2 例, 骨芽細胞腫 1 例, およ

東京医科陷科大学蔽学部第 2 口腔外科学教室（主任 : 伊藤秀夫教授)

The Second Department of Oral Surgery, Faculty of Dentistry, Tokyo Medical and Dental University (Chief: Prof. Hideo Itoh)

受付日：昭和54年 4 月 23 日
表 1 下䫟切除群の症例

\begin{tabular}{|c|c|c|c|c|}
\hline $\begin{array}{l}\text { 症例 } \\
\text { (No.) }\end{array}$ & 年跉 & 性 & 診 & 切 除 範 田 \\
\hline 1 & 7 & $\hat{o}$ & 化骨性線維畽 & 筋突起～$\overline{\mathrm{D}} \mid$ \\
\hline 2 & 8 & $\hat{o}$ & 化骨性線維腫 & 筋突起～$\overline{\mathbf{C}} \mid$ \\
\hline 3 & 11 & $q$ & 化骨性線維腫 & | $\overline{7} \sim$ 関節突起 \\
\hline 4 & 12 & $\hat{\delta}$ & エナメル上皮尰 & 「1 関節突起 \\
\hline 5 & 13 & $\hat{\delta}$ & エナィル上皮尰 & 関節突起 $\sim \overline{4} \mid$ \\
\hline 6 & 16 & $\hat{o}$ & セメント質線稚腫 & | $\overline{4}$ ～関節突起 \\
\hline 7 & 18 & $\hat{o}$ & エナメル上皮尰 & 関節突起～$\overline{4} \mid$ \\
\hline
\end{tabular}

表 2 下䭭切除十骨移植群の症例

\begin{tabular}{|c|c|c|c|c|}
\hline $\begin{array}{l}\text { 症例 } \\
(\text { No. }) \\
\end{array}$ & 年齢 & 性 & 診 & 切 除範 囲 \\
\hline 1 & 12 & q & エナメル上皮畽 & | 5 ～関節突起 \\
\hline 2 & 12 & $\hat{\delta}$ & エナメル上皮腫 & 関節突起～$\overline{4} \mid$ \\
\hline 3 & 16 & $\hat{o}$ & セメント質線維腫 & | $\overline{4}$ ～関節突起 \\
\hline 4 & 16 & $\hat{o}$ & エナメル上皮腫 & $\mid \overline{2} \sim$ 関節乫起 \\
\hline 5 & 17 & ㅇ & エナメル上皮腫 & 上行枝～$\overline{6} \mid$ \\
\hline 6 & 17 & $\hat{o}$ & 骨芽細胞腫 & $\sqrt{4 \sim 8}$ \\
\hline 7 & 17 & q & エナメル上皮腫 & | $\overline{5}$ ～関節突起 \\
\hline 8 & 18 & $\hat{o}$ & 線維性骨異形成症 & 関節突起 $\overline{3} \mid$ \\
\hline 9 & 18 & $\hat{o}$ & エナメル上皮畽 & | $\overline{5}$ ～関節突起 \\
\hline 10 & 19 & 우 & 化骨性線維尰 & $\sqrt{3 \sim 7}$ \\
\hline 11 & 19 & $\hat{o}$ & エナメル上皮腫 & $\overline{6+2}$ \\
\hline
\end{tabular}

び線維性骨異形成症 1 例で，いずれも良性の腫瘍ないし は腫瘍様病変であった（表 1，2）。

手術の内容は下靧切除のみが 7 例, 切除之骨移植の併 用が11例であった，下顎切除群の患者の年龄は，10歳未 満が 2 例, 11 15歳が 3 例, 16〜18歳が 2 例であり, ま た, 切除範囲は 5 例が関節突起を含む切除， 2 例は関節 突起部が保存された連続離断であった（表 1).

骨移植併用群の患者の年齢は, 12歳が 2 例，16〜19歳 が 9 例で, 前群よりも若干年長であり, また, 切除範囲 は 7 例が関節突起を含む切除, 4 例が連続離断であった 
第IA型

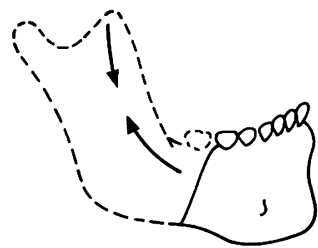

第IB型

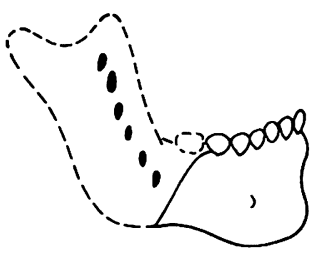

第 II 型

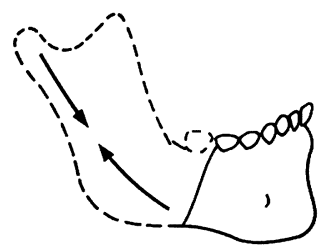

第III型

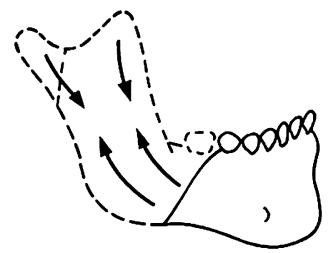

図 1 下顎切除後の骨形成像の型分類

表 3 架橋骨移植群

\begin{tabular}{r|l|l|l}
\hline $\begin{array}{c}\text { 症例 } \\
\text { (No.) }\end{array}$ & $\begin{array}{l}\text { 移植骨の } \\
\text { 種 }\end{array}$ & $\begin{array}{c}\text { 移植骨の長さ } \\
\text { (部位) }\end{array}$ & $\begin{array}{l}\text { 調查時点で } \\
\text { の骨形成像 }\end{array}$ \\
\hline 5 & 下顎骨再植 & $4.0($ 上行枝〜 $\overline{6} \mid)$ & 第 II A型 \\
6 & 自家 腸 骨 & $5.5(\mid \overline{4 \sim 8})$ & 第 II A型 \\
10 & 自 家 腸 骨 & $5.0(\mid \overline{3 \sim 7})$ & 第 II B 型 \\
11 & 下顎骨再植 & $5.5(\overline{6+2})$ & 第 I 型 \\
& (炤射後) & & \\
\hline
\end{tabular}

表 4 延長骨移植群

\begin{tabular}{|c|c|c|c|}
\hline $\begin{array}{l}\text { 症例 } \\
\text { (No.) }\end{array}$ & 移植骨の種類 & $\begin{array}{l}\text { 移植骨の長さ } \\
\text { (部位) }\end{array}$ & $\begin{array}{l}\mid \begin{array}{l}\mid \text { 調査時点 } \\
\text { の骨形 } \\
\text { 成像 }\end{array} \\
\end{array}$ \\
\hline 1 & 他家腸骨（母親） & 6.5 ( $\overline{5}$ ～関節突起 $)$ & 第 IV 型 \\
\hline 2 & 他家腸骨（母親） & 6. 0 (関節突起 $\overline{4} 1$ ) & 第 IV 型 \\
\hline 3 & 自家腸骨 & 8. $0(\sqrt{4} \sim$ 関節突起 $)$ & 第 II 型 \\
\hline 4 & 自家腸骨 & 6.0 ( $\overline{2} \sim$ 関節突起 $)$ & 第 II 型 \\
\hline 7 & 自家腸骨 & 6.0 ( $\overline{5} \sim$ 関節突起 $)$ & 第 III 型 \\
\hline 8 & 自家腸骨 & 7.0 (関節突起 $\overline{3} \mid$ ) & 第 III 型 \\
\hline 9 & 自家腸骨 & 6.0 ( $\overline{5} \sim$ 関節突起 $)$ & 第 III 型 \\
\hline
\end{tabular}

（表 2）.したがって，連続離断の 4 例には架橋骨移植， 関節離断の 7 例には延長骨移植が施行されていた。

移植骨片の種類は自家腸骨片が 7 例, 切除塊から採取 された下顎骨の健康部の再植が 2 例, 母親から採取した 腸骨片が 2 例であった。 なお，下顎骨からの骨片は，1 例はそのまま,他の 1 例にはX線の体外照射 (5,000 rad) を行ってから再植された（表 3，4）。 また，骨移植の時 期は切除值後に移植が 9 例， 1 年 4 か月後および 2 年後 移植がそれぞれ1例であった。

移植後の顎間固定法は連続画牙結森法によるものが10 例，床副子によるものが 1 例であった。 また，固定期間 は50〜90日で，平均60日であった。
表 5 下顎切除群の骨形成像

\begin{tabular}{c|l}
\hline & 症 例 数 \\
\hline 第 I A 型 & 1 (No. 3) \\
第 I B 型 & 0 \\
第 II 型 & $1($ No. 6) \\
第 III 型 & $4($ No. 1, 2, 4, 5) \\
\hline
\end{tabular}

\section{1. $\mathbf{X}$ 線写真による結果}

\section{a ) 下顎切除群}

顎切除のみの 7 例中 6 例にいろいろな程度の骨形成像

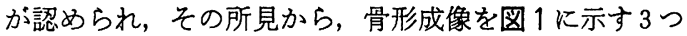
の型に分類された。

第 I 型は下顎骨の切断部と筋突起相当部を結ぶ方向に 骨形成像がみられるもので，それが棒状のものを IA, 不連続の飛び石状のものを IB とした，第 II 型は下顎骨 の切断部と関節突起相当部を結ぶ方向に骨形成像がみら れるものであり，第正型はその両方向がみられるもので ある.

この分類に従って症例を検討すると，1 例はIA 型に， 1 例は II 型に，4 例はIII 型にそれぞれ該当すると思われ た（表 5)。第 IA 型に該当する症例（No．3）は11歳の 女児で，術後 1 年 4 か月のX線写真で棒状のやや太い骨 形成像が観察され，下顎骨に接続していた（写真 1). II 型に該当する症例（No. 6) は16 歳の男性で，術後 4 年のX線写真で, 飛び石状に小塊状の骨形成がみられた (写真 2). III型に 該当する 4 例のらち， 7 歳 (No. 1) および 8 歳 (No. 2) の症例は関節突起のみを残して切 除されたものであるが，それぞれ術後 3 年および 1 年 6 か月のX線写真で，かなり大量の骨形成像が観察され， 


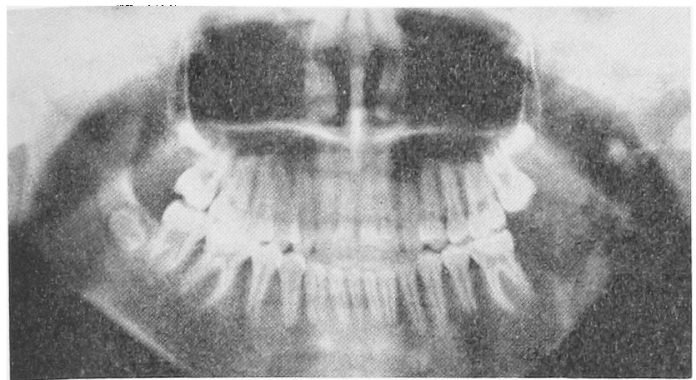

写真 1 下顎切除群 No. 3 の 1 年 4 か月後 (13歳) のX線写真

I A 型の骨形成像がみられる

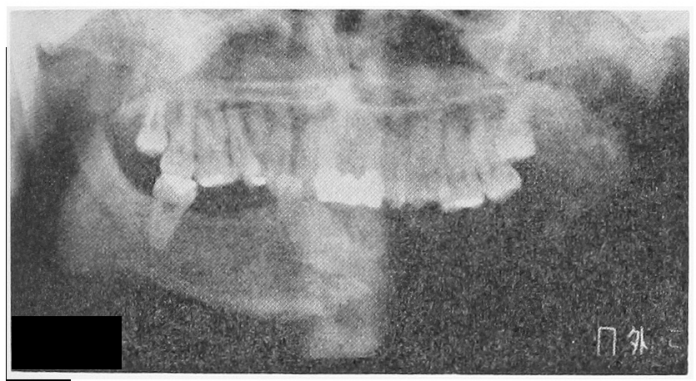

写真 2 下䫇切除群 No. 6 の 4 年後（20歳）のX線 写真

II 型の骨形成像がみられる
不十分ではあるが，下靧枝の形が回復されているように 思われた，骨形成像は関節突起と連続していたが，下顎 体部との間には細い透過像が介在しており（写直3，4）, 触診でもそこに偽関節が形成されていた，他の 2 例は12 歲 (No. 4) および13歳 (No. 5) の男児で, 関節離断が 行われたるのであるが，それぞれの 8 年後および 7 年後 のX線写真で，同様な相当量の骨形成像がみられたが， 量的には前の 2 例よりもやや少なかった（写真 5)。乙 かし，関節突起様の形態が形成されている点が注目され た. なお，No. 7 の18歳の男子の関節離断の症例には骨 形成像がみられなかった。

以上のごとく，下顎切除群の 7 例中 6 例消形成像が みられたが，患者の年齢蛙よび隀瘍の種類と骨形成量と の関係は明らかでなかった。

b) 下顎切除十骨移植群

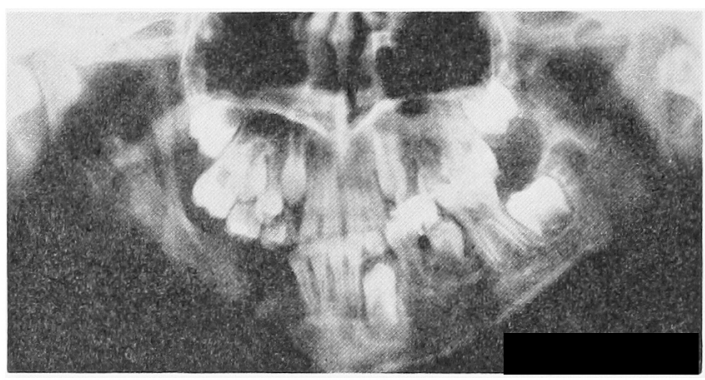

写真 3 下顎切除群 No. 1 の 年後 (10歳) のX線 写真

III型の骨形成像がみられる

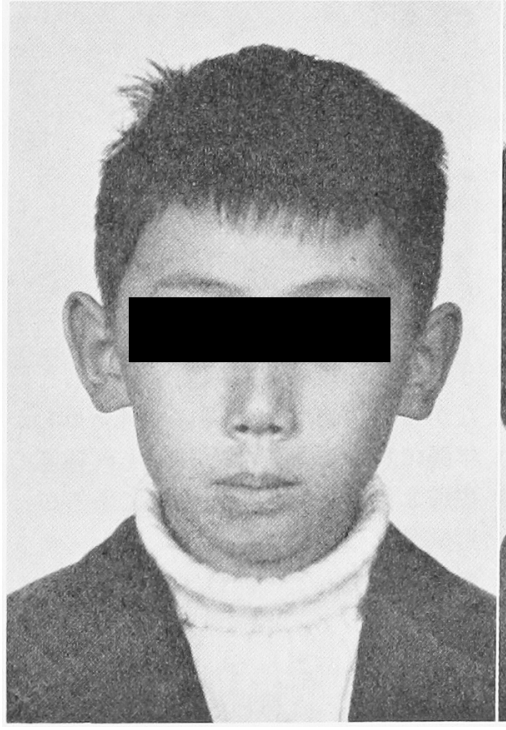

正 面

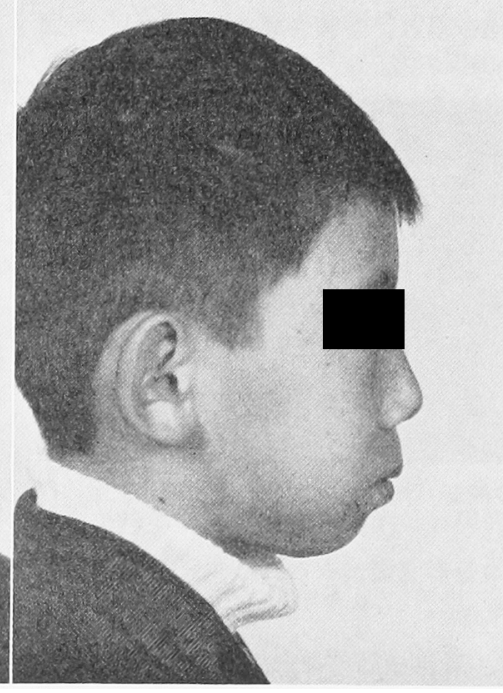

患側側面

写直 4 No. 1 症例の術後顔写真 


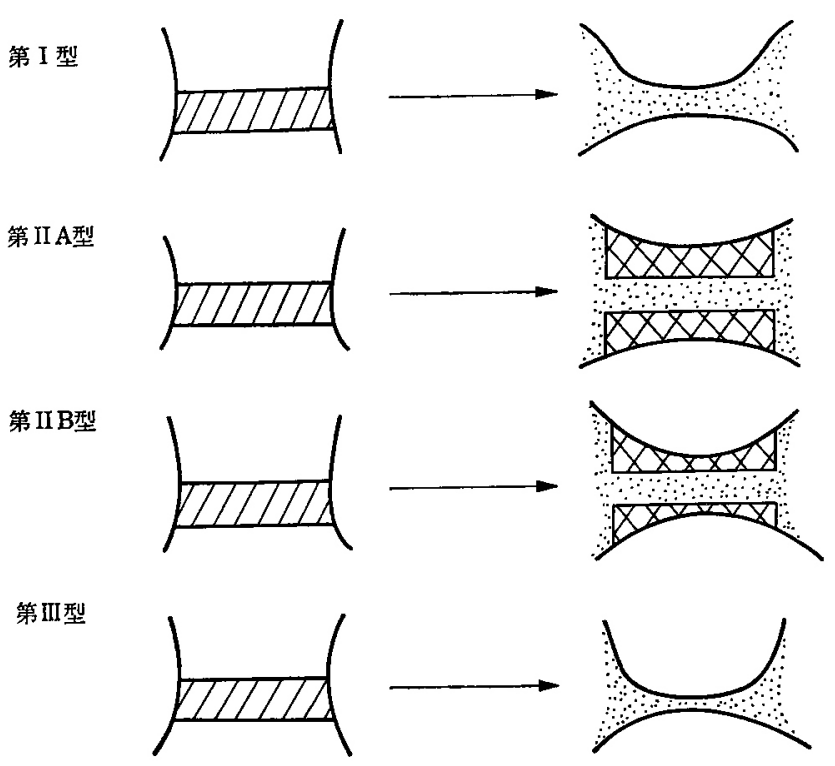

図 2 架橋骨移植後の骨形成像の型分類

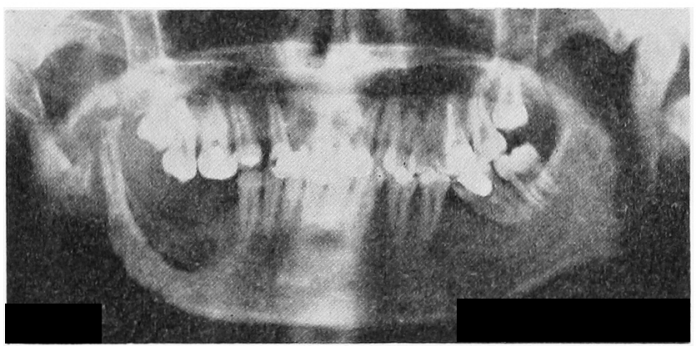

写真 5 下罰切除群No. 5 の 7 年後 (20歲) のX線 写真

III型の骨形成像がみられ，下頕骨に連続している

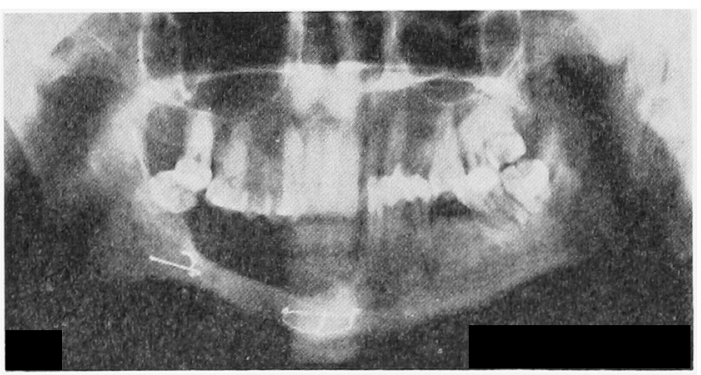

写真 6 架橋骨移植群 No. 11 の 年後 (19歳) の $\mathrm{X}$ 線写真

I 型の骨形成像がみられる

イ）架橋骨移植群：骨移植部の骨形成状態を教室の分 類2（图2）によって検討した結果，I型，すなわち，

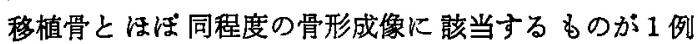

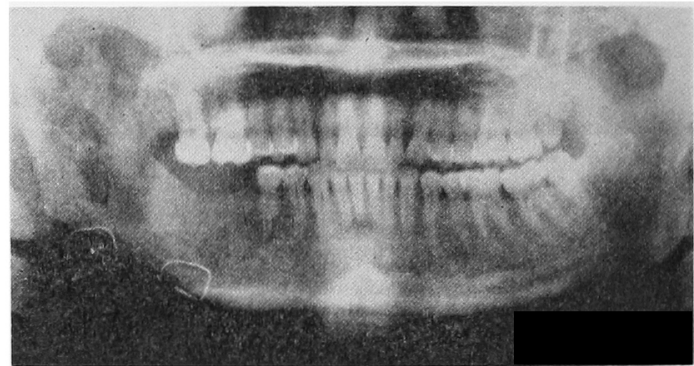

写真 7 架橋骨移植群 No. 5 の10年後 (27歳) のX 線写真

II A 型の骨形成像がみられる

(No. 11, 写直 6)，IIA型，すなわち，移植骨よりも著 しく太い骨形成像に該当するものが 2 例 (No. 5 および 6, 写真 7，8）で, II B型, すなわち，移㥀骨よりもか なり太い骨形成像に該当するものが 1 例 (No. 10 , 写真 9）で，移植骨より細くなった第型に該当する症例は なかった，移植骨の長さは $4.5 \mathrm{~cm}$ から $5.5 \mathrm{~cm}$ の間，

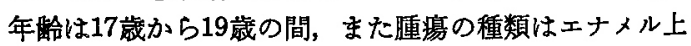
皮尰 3 例，骨芳細胞腫 1 例であるが，これらの因子と骨 形成量との関係は明らかでなかった。しかし，移植骨片 の種類別でみると，自家腸骨移植の 2 例はII A たたII B型に該当し，下箩骨再植がII A型，X線照射下顎骨再 植か゚I 型に䬶当しているので (表 3)，移植骨の条件とし ては若干苏ると思われるX線照射骨です，被移植野の条 件次第では十分有用性があることを示唆していた。ま， 移植部位との関係をみると，下顒体部の 3 例では I 型ま 

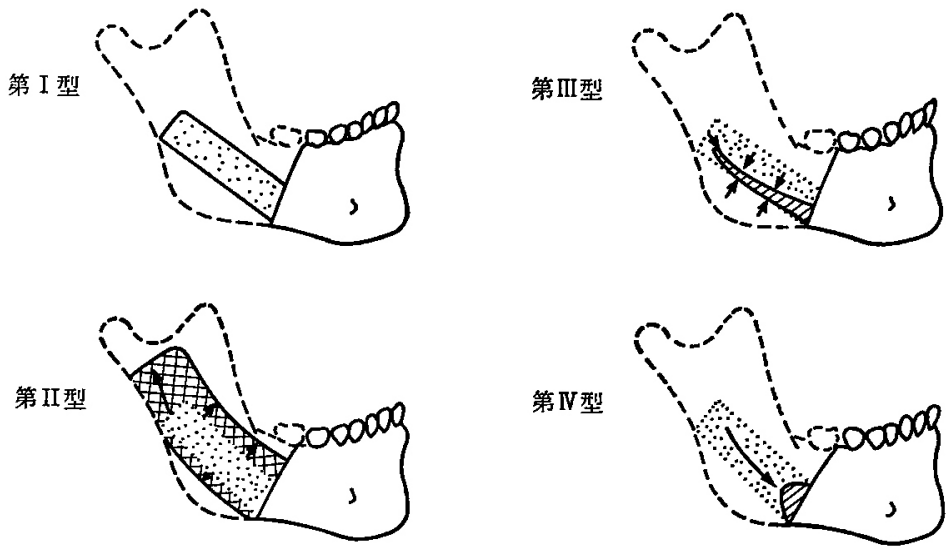

図 3 正長骨移植後の骨形成像の型分類

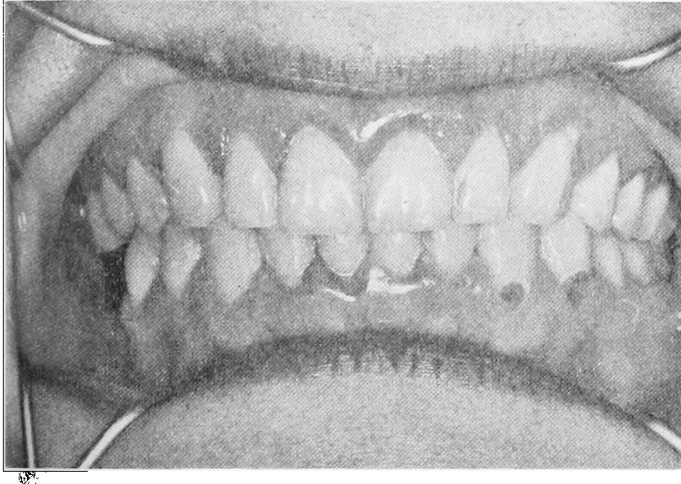

写真 8 No. 5 症例の街後口腔写真

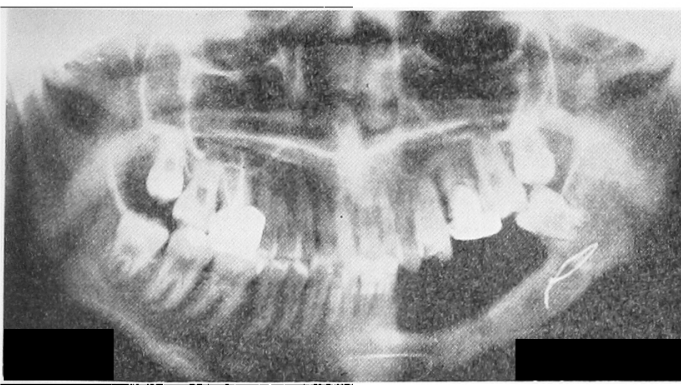

写真 9 架橋骨移植群 No. 10 の 2 年後 (21 歳) の $\mathrm{X}$ 線写真

II B型の骨形成像がみられる

たは】 B型であり，曰歯部から下顎枝部にわたる1例で は】A型の骨形成像がみられたことが注目された。

口）延長骨移植群：下顎切除後に延長骨移植が行われ た7例のすぺてにいるいろな骨形成像が認められた。

これをわれわれが定めた基準（図了）と照合すると， 結果は表 4 のようで，I 型，すなわち，移植骨とほぼ同 程度の骨形成像に該当するものはなく，I型すなおち，

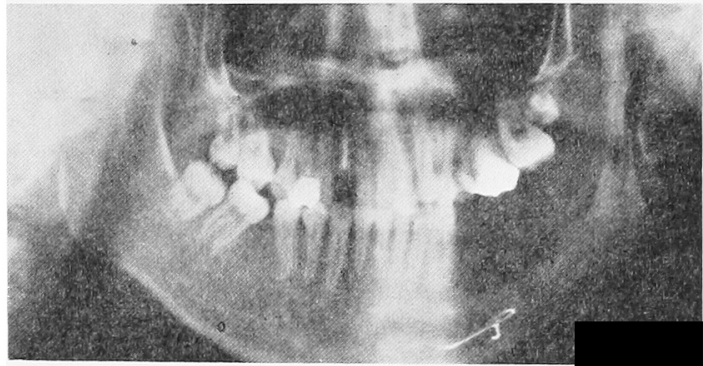

写真 10 延長骨移植群No. 3 の 2 年後のX線写真 II 型の骨形成像がみられ，関節突起相当部にも骨 形成がみられる

移植骨よりも長さおよび太さが成長した骨形成像に該当 するむのか゚ 2 例あった。 その最る顕著なのは No.3の 症例 (16歳) で, 術後 2 年のX線写真で著しい骨成長像 がみられ，その後端は筋突起様の形をなしていた。関節 突起部にもそれとは別の骨形成像がみられたが，両者は 細い透過像で隔てられていた（写真 10）．写真11は術後 の顔貌写真である. 他の 1 例は No. 4 の症例 (16歳) で, 術後10年のX線写真で著明に延長した骨形成像がみ られた (写真 12).

また， II 型，すなわち先細りの骨形成像（写直13）に 該当する 。のか3 3 例 (No. 7，8，9）で，第IX型，すな わち移植骨がほとんど吸収されたと思われるよらな少量 の骨形成像（写真14）に該当するものが 2 例 (No. 1 お よび2) であった.

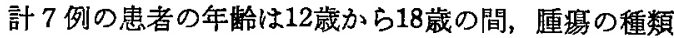
はエナメル上皮尰が 5 例，せメント質線維腫と化骨性絈 維尰がそれぞれ 1 例であり，また，移植骨片の長さは $6.0 \mathrm{~cm}$ から $8.0 \mathrm{~cm}$ の間であるが，これらの因子と骨形 成量との関俰は明らかでなかった，しかし，自家腸骨移 植の 5 例の結果は第 II 型 2 例，第型 3 例とほぼ安定性 であったのに対して，母親の腸骨片を用いた 2 例の結果 


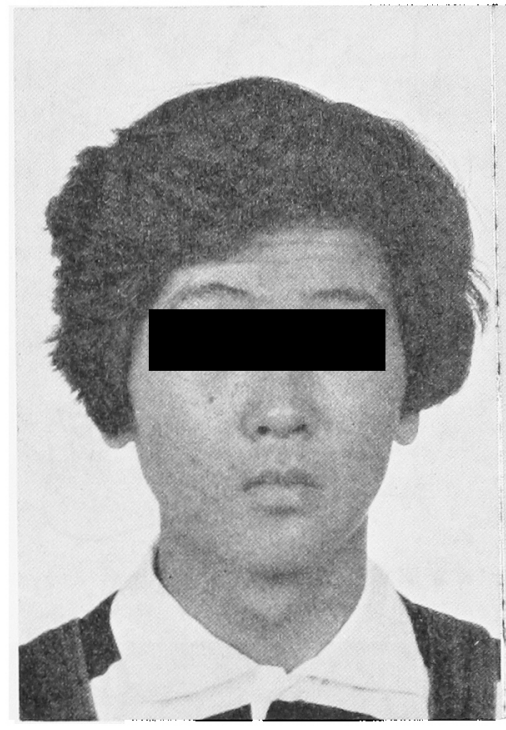

正 面

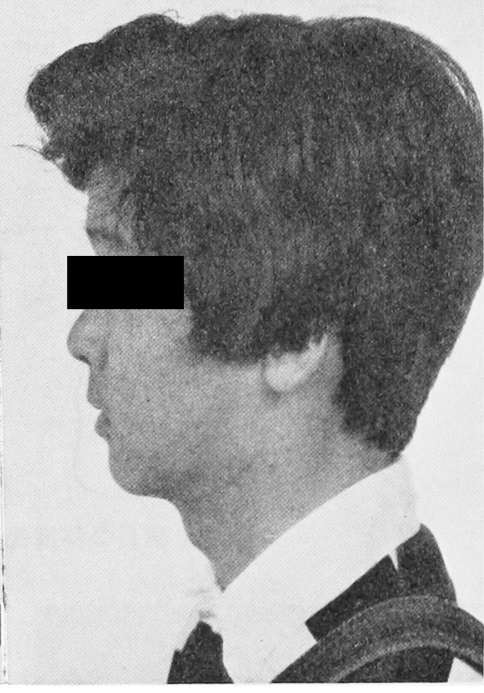

患側側面

写真 11 No. 3 症例の術後顔写真

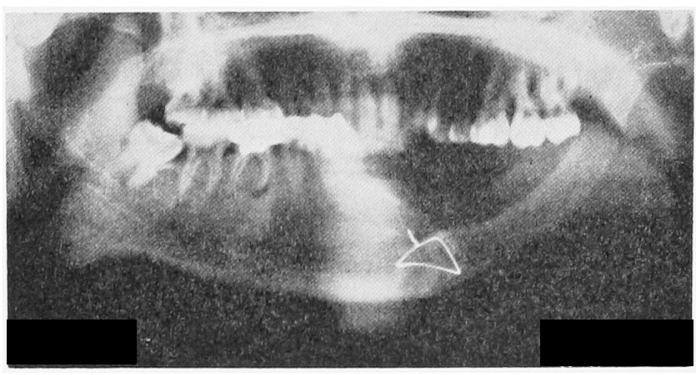

写真 12 延長骨移植群 No. 4 の10年後のX線写真 II 型の骨形成像がみられる

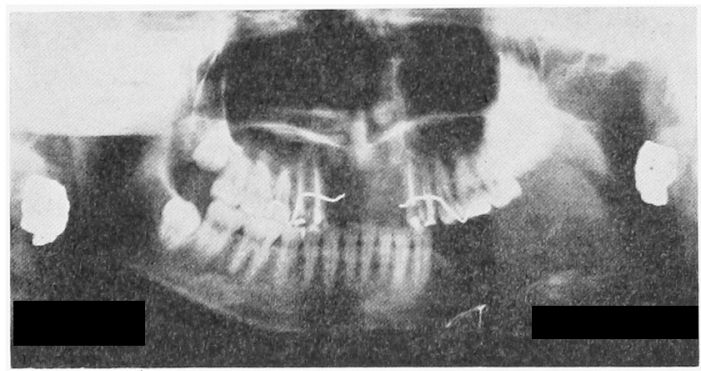

写真 13 延長骨移植群 No. 7 の 2 年後（20歳）の $\mathrm{X}$ 線写真

II 型の骨形成像がみられる

はいずれる第 $V$ 型に終わっているので，その適度症の選 択には慎重を要すると思われた。

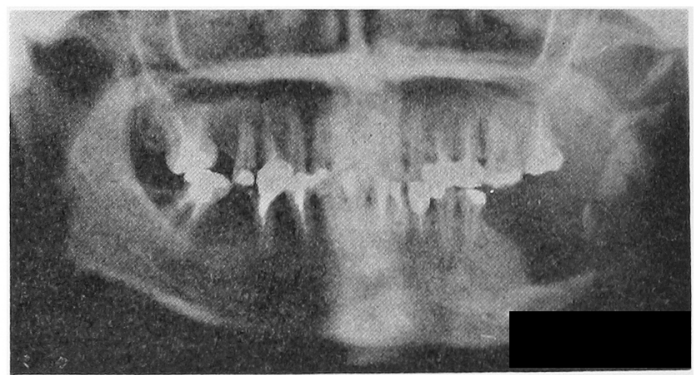

写真 14 延長骨移植群No. 1 の 9 年後（21歳）の X線写真

IV型の骨形成像がみられる

\section{2. 顔貌および咬合状態}

下顎切除群の 7 例の寸べてに，正面顔貌に，手術側の 陷凹による多少の非対称性がみられたが，第且型の著明 な骨形成像が認められた 2 例(No. 1 および2) では変 形が極めて軽砫であった，写直 4 はNo. 1 の切除後 3 年 の顔写真である、また，咬合関係をみると，咬合時では 下簤中切歯間の正中線の平均 $5.5 \mathrm{~mm}$ の切除側への偏位 がみられ，また開咬時では約 $8.5 \mathrm{~mm}$ の偏位がみられ た。一般に, 偏位の小さな症例は顔貌の変形が少なく, 存位の大きい症例は变形も大さいように思われた。

架橋骨移植群の 4 例中, 顔貌の変形がめだったのは1 例のみで，他の3 例は左右の対称性がかなり良く保たれ ており，下䫛の偏位は咬合時で $3 \mathrm{~mm}$ 以下，開口時で平 均約 $5 \mathrm{~mm}$ であった。 写真 8 は No. 5 の 10 年後（27歳 時）の咬合時の写真である。 
延長骨移植群の 7 例の下䫇の偏位は咬合時で平均約 6 $\mathrm{mm}$, 開口時で平均約 $10 \mathrm{~mm}$ で，3 群の中では最も大き く，したがって，正面顔貌に非対称のある症例も多かっ たが，第I型に該当する著明な骨形成像がみられた No. 3 の症例は, 顔貌の変形は極めて 軽微であった（写真 11).

な括，全切除症例の相当数が，患側の下口唇部の軽微 な異和感を訴えたが, 痛覚に異常值がみられるほどのも のではなく，下口唇の動きには全く支障がないとのこと であった.

\section{考察}

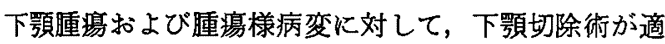
用された症例の報告は極めて多いが，その長期経過に関 しては，骨移植併用例についての移植経過を中心とした

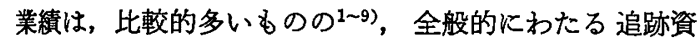
料に基づいた検討は十分とはいえないように思われる。 そこでわれわれは，過去13年間に当科で下須切除が行わ れた129 例について予後調查を行ったが，その結果か ら，成長期の作少者と成人とでは，経過の面で多少とも 異なる点があるように思われたので，まず，年少患者に

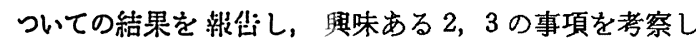
た.

\section{1. 顈骨切除単独群について}

当科では，成朕制の年少患者に対しては，顔面形態， 䫑の発育ならびに鄂機能などの点から，できるかぎり下 影骨の耀断切除を洧けて，部分切除術を適用する方針を

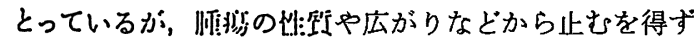
影切除を行わざるを得ない症例がある．その場合には通 常骨移推が行われているが，母床組織の状態，補填すべ き骨欠損の範囲と採取可能な骨片の大きさとの不均衡，

あるいは十分な顎間固定ができないなどの理由から，下 䪿切除のみにとどめざるを得ない症例がある．今回調査 した18例のらち，関節離断を行った 7 例がこれに該当し たが，その長期経過をみると， 7 例中 6 例にいろいろな 程度の骨形成像が認められ，そのらち 4 例は开型に属す る著明な骨形成像を示し，不完全ながら下顎枝部の形態 を復元するような傾向のものもあった。このような症例 は顔貌の術後变形が少なく，1 例は手術前とほとんど変 わらない状態であった。

下顎切除後の骨形成については, Byars $5^{10,11)}$ の化骨 性線維腫で下䫇切除された 8 歳の子供に骨の形成がみら れたとの報告があり，また Kazanzian ${ }^{12)}$, Francksen ${ }^{13)}$, Haunfelder ${ }^{14)}$, Steinhard $t^{15)}$, Steinhäuser ${ }^{16)}$, 西嶋 $ら^{17)}$ および Adekeye ${ }^{18)}$ の報告があり，いずれも骨膜を可及的 に保存することによって，骨の新生がみられたと述べて いる。 また上颓骨では，Körlof ら ${ }^{19)}$ が黒色性神経外肧 葉性腫劰のために, 上顎切除が行われた生後 4 か月の女
児で，その後に骨が再生された症例を報告しており，わ れわれがさきに報告した同腫瘍の症例20)でも，10年後の 調查では，注正常に近い上須骨の形態が復元されてい た．下顎切除部分の著明な骨形成は成人でもみられるこ とがあるが14,16)，その多くは20歳以下の年少者であり， われわれの報告例の年龄は15歳以下が 5 例，16歳が 1 例 であった。

このような骨の新生，あるいは再形成は一般に母骨切 断部，および温存された骨膜の 部分からといわれてい る.Weiss ${ }^{21)}$ は幼犬を用いた実験で，骨膜を保存して関 節離断を行ったところ，切除部分のほぼ全域に骨の再生 がみられたと述べている。また，橋本ら22)は骨吸収の著 明な下顎癌に放射線療法と化学療法が行われた 57 歳の男 性で，その14か月後に骨の再形成像がみられた症例を報 告し，それは放射線照射に耐元て残存した骨膜が炎症性 刺激によって，骨新生能が賦活された結果ではないかと 述べている。われわれの7例はいずれる腫演が大きく， 部分的には骨膜を含めて除去された症例 (No. 1 打よび 4) ああるが，骨膜が除外されたと思われる部分にも骨 形成像がみられたので，骨の成長あるいは代謝の旺盛な 成長期では，条件しだいでは既存の骨膜によらない骨新 生が生しる可能性も，否定できないように思われる。

\section{2. 骨移植群について}

下顎切除後の顎機能ならびに顔面の審美的障害を回復 するために，通常は骨移植による再建が行われており， 骨移植の成績 および 実験的研究も多数報告もされてい る らびに臨床的1,2,29 31) に検討してきたが，新鮮自家腸骨 移植が最も安全，また確実であると結論されている，今 回の19歳未満の骨移植例は11例であるが，そのうち，自 家骨移植を行ったのは架橋骨移植 4 例の全例と, 延長骨 移植 5 例中の 2 例の計 6 例は全く経過が良好で，母骨と 接合されており，骨移植の目的がほぼ達成されていた。

架橋骨移植は延長骨移植に比較して顔面の対称性をそ こならことが少なく，ことに即時骨移植は良好な結果が 得られるようである. しかし，切除後に間隔をおいて二 次的沿移植が行われる場合には，下領枝の上部は洀痕 や咀獣筋によって，内上方に率引されていることが多い ので, 架橋骨移植を行っても，下顎角部のふくらみを再 現することが困難な場合が多く，患側が扁平となって顔 貌の対称性が失われやすいとされている25).われわれの 4 例は, 2 例は腸骨, 2 例は下顎骨の即時移植または再 植であり, 顔貌の変形および顎の偏位が少なく、ほ满 足できる結果であった。

一方，延長骨移植では，母骨と連結は一端だけで，遠 心側は遊離端であるので, 骨片の固定が不安定であり, 周囲組織の瘦痕収縮や咀喓筋の影響を受けやすく，患側 への頱の偏位および顔貌の変形が起こりやすい．工藤 ら ${ }^{24)}$ はこの欠点を改善するために, できる限り関節突起 
を保存して、これと下靧体部とに架橋様に骨移植を行う

と，良好な成績が得られたと報告している，われわれの 症例では, 自家腸骨移植の 3 例に III 型, すなわち先き細 りの骨形成像がみられ，下䫇角部の扁平化や䫇の偏位が みられた。しかし，他の 2 例では骨形成像が極めて著明 で, 遠心端が 1 例は筀突起相当部に，また他 1 例は関節 部にまで達しており，偏位が比較的少なく，また顔貌の 対称性もほぼ保たれていた。电親の腸骨を用いた延長骨 䔟植例の 2 例は，いずれも著明に吸収されていた．工藤 ら ${ }^{23)} 8$ 歳の少女に母親の腸骨移植を行ったが, 術後感 染のために移植骨を除去した症例を報告し，その原因を 移植免疫反応に求めている。術後感染と移植免疫との関 係についての言及は避けたいが，他家骨移植の場合には 移植免度機構が働いて，移植骨が吸収されることが多い ことを考えると，母親の骨を用いた場合で，同様な何ら かの影響を無視することはできないと思われる．この 2 例で注目されたのは，移植骨とは無関係に塊状の骨形成 像がみられた点であって，これと前述の下顎切除群の結 果とを考兄ると，年少者の場合には，他家骨移植を行う よりす，むしろ切除のみにとどめて扣いたほらが，良い のではないかとも思われた。

以上の結果から，成長期の年少患者の場合には，下顎 切除ならびに骨移植の基本に忠実であるだけでなく，年 龄的な特徽を十分に考慮して，手術法を選択することが 必要であり，また，下顎切除のみの場合には顎の偏位予 防に留意することが必要であると思われた。

結語

約13年間に当科で行われた 20 歳未満の下顎切除症例 18 例について遠隔調査を行い, 次のような結果を得た。

1) 18 例の内訳は下靧切除のみが 7 例，切除後に骨移 植が11例であった。

2）下顎切除の 7 例のうち，6 例にいろいろな 程度の 骨再形成像がみられ，特に 4 例はそれが著明であった。

3）架橋骨移植併用群は 4 例で，5ち 3 例には架橋部 が成長しており，4 例ともほ涪満足すべき結果であっ た.

4）延長骨移植併用群は 7 例で，骨成長のみられたの か 2 例, 細化傾向を示したもの 3 例, 拉よび著明な吸収 がみられたのが 2 例であった。吸収がみられた 2 例は母 親から採取した腸骨移植であった

5）多くの症例に顔貌の変形がみられたが，それが極 めて軽微な症例は下靧切除群の 7 例中 2 例, 架橋骨移植 群の 4 例中 3 例, および延長骨移植群の 7 例中 1 例の計 6 例であった。

本論文の要旨は第32回日本口腔科学会総会において発 表した。

\section{引 用 文 献}

1）中村平藏：影部骨移植について。 日口外誌 2 : 1051956.

2）加子龍一郎, 他: 㴿部骨移植の臨床的研究, 第 2 報 初期移植経過飞ついて (抄). 日口外誌 13: 801967.

3）松本秀次：下顎骨移植の臨林的ならびに央験的 研究. 軍医団雑誌 348: 5611942 .

4) Blocker, T.G., Weiss, L.R.. Use of cancellous bone in repair of defects about jaws. Ann Surg 23: 6221964.

5) Macomber, W.B., et al.. Mandibular bone grafts. Plast reconstr surg 3: 5701948.

6）佐藤伊吉：下䫟における骨移植の臨床的研究。 歯科学雑誌 6: 941949.

7) Richter, H.E., Boyene, P.J.: New concepts in facial bone healing and grafting procedures. J oral surg 27: 5571969.

8) Dechamplain, R.W.: Mandibular reconstruction. J oral surg 31: 4481973.

9) Sehdev, M.K., et al.: Ameloblastoma of maxilla and mandible. Cancer 33: 3241974.

10) Byars, L.T.: Subperiosteal mandibular resection with internal bar fixation. Plast reconstr surg 1: 2361946.

11) Byars, L.T., Mcdowell, F.: Presevation of jaw function following surgery and trauma. Surg gynec obstet 84: 8701947.

12) Kazanzian, V.H.: Spontaneous regeneration of bone following excision of the mandible. Amer J orthodont 32: 2421946.

13) Francksen, U.: Periosteal regeneration des unterkiefers nach halbseitiger Exartikulation. Fordts Kiefer Gesictschir 4: 3371958.

14) Haunfelder, D.: Uber die Regeneration des Unterkiefers nach subperiostaler Resektion und Exartikulation. Chirurg 33: 621962.

15) Steinhardt, G.: Bewahrte Operations Methode bei "semimalignen" Geschwulsten der Kiefer. Dtsch z mund kieferh 49: 241967.

16) Steinhäuser, E.: Unterkiefer Reconstruction durch intraorale Knochentransplantate, deren Einheilung und Beeinflusung durch die Funktion eine tierexperimentalle Studie. Schweiz msch Zahnheil 782: 2131968.

17）西嶋克巳，他：下顎頭を含めた下靧骨片側猏断

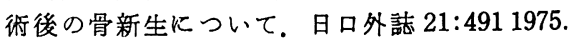

18) Adekeye, E.O.: Rapid bone regeneration subsequent to subtotal mandiblectomy, report of an usual case. Oral surg 44: 5211977.

19) Körlof, B., Bergstrom, R.: Melanotic progonoma of the maxilla. Acta chir Scand 29: 2921965. 
20）名倉英明, 他：いわゆる黒色エナメル上皮腫の 1 例. 口科誌 18: 1341969 .

21) Weiss, P.: Unterkiefer und Kiefergelenk-regeneration nach subperiostaler Unterkiefer Exartikulation am jungen Hund. Dtsch Zahnarztl Z 24: 3551969.

22）橋本賢二，他：治療後に骨新生がみられた下顎 癌の 1 例. 日口外訰 24:396 1978.

23) 工藤啓吾, 藤岡幸雄 : 下顎骨骨移植の臨床的研 究. 日口外誌 $21: 1801975$.

24) 工藤啓吾, 他: 下顎部骨移植の臨床的研究, そ の 2 関節突起部への骨移植症例について. 日 口外誌 22: 8161976.

25）上野正：骨移植術と口腔外科における応用。
歯界展望 33：614 1969.

26) 中島政彦：眝蔵骨移植の実験的研究. 口病誌 22: 2551955.

27) 河村正昭：顎部骨移植の実騟的研究. 口病誌 26: 20571959 .

28）朝倉昭人：顎部冷凍骨架橋移植に関する実験的 研究. 口病誌 29: 2811962.

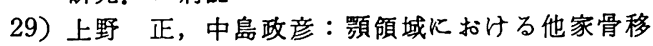
植の成績。口病誌 21: 1981954.

30) 上野 正：骨移植による顎骨形成手術。形成外 科 6: 1921963 .

31) 中村平蔵編：最新口腔外科学. 第 2 版, 医菌薬 出版, 東京, 1975, 263頁. 